\title{
Immunitet urzędującej głowy państwa - kilka uwag na marginesie spraw toczących się przed Międzynarodowym Trybunałem Karnym
}

\section{Wstęp}

Sprawa Omara Al Bashira, urzędującego prezydenta Sudanu, przed Międzynarodowym Trybunałem Karnym (dalej MTK lub Trybunał) na nowo ożywiła dyskusję dotyczącą immunitetu chroniącego przywódców państw czy członków rządu podczas postępowań przed międzynarodowymi trybunałami karnymi (stałym i trybunałami ad hoc). Dyskusja ta nasiliła się, kiedy prezydentem Kenii został, oskarżany przez MTK o popełnienie zbrodni przeciwko ludzkości, Uhuru Kenyatta.

Praktyka w zakresie osądzania przed sądami międzynarodowymi urzędujących przywódców państw jest bardzo skromna. Jako przykłady można wskazać próby osądzenia Slobodana Miloševicia i Charlesa Taylora. Rudymentarne doświadczenie w tym zakresie nie oznacza, że nie próbowano wcześniej osądzić przywódców państw ${ }^{1}$, ale raczej wskazuje na to, jak wielkie kontrowersje towarzyszą osądzaniu osób objętych immunitetem. Zarówno sto lat temu, jak i dziś, pomimo istnienia szeregu instrumentów prawa międzynarodowego, postawienie przed sądem osoby objętej immunitetem głowy państwa stanowi nie lada wyzwanie. Problemy z tym związane pozwalają jednak na sformułowanie kilku uogólnień.

${ }^{1}$ Można się nawet w tym zakresie odwołać do nieudanej próby postawienia przed specjalnym trybunałem cesarza Wilhelma II Hohenzollerna, szerzej L. Gardocki, Zarys prawa karnego międzynarodowego, PWN, Warszawa 1985, s. 27-31, B. Krzan, Immunitet głowy państwa a bezkarność za popetnienie zbrodni międzynarodowych - uwagi na tle sprawy prezydenta al Bashira przed MTK, [w:] A. Wnukiewicz-Kozłowska (red.), Aksjologia wspótczesnego prawa międzynarodowego, Wydawnictwo Uniwersytetu Wrocławskiego, Wrocław 2011, s. 69 i nast. 
Co do zasady immunitet głowy państwa czy członka rządu związany jest z immunitetem państwa i immunitetami dyplomatycznymi. Jak wskazuje doktryna, głowie państwa przysługuje immunitet ratione personae, obejmuje on wszelkie czynności tak prywatne i służbowe osoby, która się nim posługuje, wygasa jednak w chwili złożenia urzędu. Po tym czasie byłą głowę państwa chroni immunitet ratione materiae (immunitet funkcjonalny/materialny), odnosi się on jednak tylko do działań mających charakter obowiązków służbowych ${ }^{2}$. Z zastrzeżeniem pewnych wyjątków ${ }^{3}$ immunitet urzędującej głowy państwa uważa się za immunitet absolutny. To przekonanie wiąże się $\mathrm{z}$ tradycyjnym postrzeganiem państw jako suwerennych i równych podmiotów we wzajemnych relacjach (stosownie do brzmienia łacińskiej paremii par in parem non habet imperium). Chodzi o ochronę interesów państwa reprezentowanego przez daną osobę, której przyznaje się immunitet w czasie pełnienia przez nią funkcji; aresztowanie takiej osoby mogłoby zdestabilizować stosunki między państwami, dlatego zwyczajowo utrzymuje się, że w czasie pełnienia funkcji pozostaje ona nietykalna.

$\mathrm{W}$ doktrynie istnieje jednak zgoda co do tego, że w przypadku popełnienia zbrodni międzynarodowych należy wyraźnie oddzielić działanie państwa od działania głowy państwa ${ }^{4}$. Popełnienia zbrodni nie można nazywać aktem państwa, dlatego popełnienia zbrodni nie należy przypisywać państwu, ale właśnie jednostce $^{5}$. H. Kelsen w klasycznej już pozycji General theory of law and state wskazuje , ,...) an individual, in performing an illegal act, cannot be considered to be an organ of the state" ${ }^{\text {. W }}$ szczególności wskazuje się, że państwo jako twór abstrakcyjny nie może samo popełnić zbrodni ani odpowiadać za jej popełnienie, dodatkowo jednostka nie może powoływać się na swoją oficjalną pozycję, aby uwolnić się od odpowiedzialności za popełnienie takiego aktü

O ile można stwierdzić, że w doktrynie panuje zgoda co do karalności osób popełniających zbrodnie międzynarodowe, nie można jednoznacznie stwierdzić, że ma to swoje odzwierciedlenie w praktyce państw czy sądów. Dlatego spra-

${ }^{2}$ Por. S. Zappalà, Do Heads of State in Office Enjoy Immunity from Jurisdiction for International Crimes? The Ghaddafi Case Before the French Cour de Cassation, EJIL (2001), vol. 12, no. 3, s. 598; W. Czapliński, A. Wyrozumska, Prawo międzynarodowe publiczne, zagadnienia systemowe, Wydawnictwo Beck, Warszawa 2004, s. 247 i nast.; Y. Simbeye, Immunity and international criminal law, Ashgate Publishing 2004, s. 109 i nast., B. Krzan, op. cit., s. 63 i nast.

${ }^{3}$ O czym niżej.

${ }^{4}$ Y. Simbeye, op. cit., s. 127.

${ }^{5}$ Ibidem, s. 128. Odnieść się także można do słynnej i wielokrotnie przywoływanej w literaturze przedmiotu frazy z wyroku Trybunału norymberskiego „Crimes against international law are committed by men, not by abstract entities...", por. Trial of the Major War Criminals before the International Military Tribunal, Nürnberg, 14 November 1945-1 October 1946, Nürnberg, Germany, 1947, s. 223.

${ }^{6}$ H. Kelsen, General theory of law and state, Clark, New Jersey 2009, s. 359.

7 Y. Simbeye, op. cit., s. 129.

8 A. Watts, The International Law Commission 1949-98: Final draft articles and other materials, Oxford 1999, s. 1706. 
wa Al Bashira, a konkretniej - nakazów aresztowania skierowanych przeciwko niemu, wydanych przez prokuratora Międzynarodowego Trybunału Karnego ${ }^{9}$, otworzyła na nowo dyskusję dotyczącą immunitetu, jako że Al Bashir od 1993 r. jest urzędującym prezydentem Sudanu. Jest jednocześnie pierwszym urzędującym prezydentem oskarżonym przez MTK. Obecnie przed MTK toczy się także sprawa przeciwko urzędującemu prezydentowi Kenii Uhuru Kenyatcie, któremu przedstawiono zarzuty dokonania zbrodni przeciwko ludzkości ${ }^{10}$ zanim w 2013 r. został wybrany na prezydenta Kenii. Jest więc także urzędującym prezydentem. Zarzuty dotyczące popełnienia zbrodni przeciwko ludzkości objęły również jego zastępcę Williama Ruto i toczy się przeciwko niemu postępowanie przed trybunałem ${ }^{11}$.

Sprawy Bashira, Kenyatty i Ruto rzucają światło w szczególności na dwie kwestie, które w toku opracowania postaram się przybliżyć, chodzi mianowicie o współpracę państw z Trybunałem (tu w szczególności należy dokonać rozróżnienia na państwa niebędące stronami Statutu MTK i jego państwa strony), a także o immunitet głowy państwa z uwzględnieniem przypadku Bashira i Kenyatty w kontekście działań Trybunału.

\section{Współpraca państw z MTK - zagadnienia ogólne}

Zgodnie z postanowieniami Statutu rzymskiego (dalej także jako Statut lub Statut MTK) ${ }^{12}$ państwa-strony są zobowiązane do współpracy z trybunałem „W zakresie ścigania i osądzania zbrodni podlegających jurysdykcji Trybunału” (art. 86 Statutu). Trybunał zwraca się do państw-stron z wnioskami o współpracę w trybie art. 87. Na podstawie art. 87 ust. 5 może także zwrócić się do państwa niebędącego stroną Statutu o udzielenie pomocy prawnej (także na podstawie art. 89 Statutu Trybunał może przekazać wniosek o aresztowanie osoby i przekazanie jej jakiemukolwiek państwu, na którego terytorium dana osoba może się znajdować). O ile jednak państwo niebędące stroną nie zawarło z Trybunałem

${ }^{9}$ W rzeczywistości chodzi o dwa nakazy aresztowania, pierwszy z 2009 r. dotyczący zbrodni przeciwko ludzkości i zbrodni wojennych (por. PTC I, Warrant of arrest for Omar Ahmad Al Bashir, ICC-02/05-01/09, 4 marca 2009 r., na stronie: http://www.icc-cpi.int/iccdocs/doc/doc639078.pdf.) i drugi z 2010 r. dotyczący dodatkowo zbrodni ludobójstwa (por. PTC I, Second Warrant of arrest for Omar Ahmad Al Bashir, ICC-02/05-01/09, 12 lipca 2010 r., na stronie: http://www.icc-cpi.int/ iccdocs/doc/doc907140.pdf.).

${ }^{10}$ PTC II, Decision on confirmation of charges pursuant to article 61 (7) (a) and (b) of the Rome Statute, ICC-01/09- 02/11, 23 stycznia 2012, na stronie: http://icc-cpi.int/iccdocs/doc/doc1314543.pdf.

${ }^{11}$ PTC II, Decision on confirmation of charges pursuant to article 61 (7) (a) and (b) of the Rome Statute, ICC-01/09- 01/11, 23 stycznia 2012, na stronie: http://icc-cpi.int/iccdocs/doc/doc1314535.pdf.

12 Dz. U. z 2003 r., nr 78, poz. 708. 
umowy czy porozumienia w sprawie współpracy, Trybunał nie jest w stanie w żaden sposób takiej współpracy wyegzekwować. Również Zgromadzenie Państw Stron nie zostało wyposażone w środki, które pozwalałyby mu na podjęcie innych niż dyplomatyczne działania ${ }^{13}$. Jednym słowem nieudzielenie współpracy czy jej odmowa przez państwo niebędące stroną Statutu nie łączy się z żadnymi konsekwencjami natury prawnej ${ }^{14}$.

\subsection{Sprawa Bashira}

Dnia 31 marca 2005 r. na mocy rezolucji 1593 Rada Bezpieczeństwa Organizacji Narodów Zjednoczonych ${ }^{15}$ (dalej jako Rada lub RB), działając w oparciu o rozdział VII Karty Narodów Zjednoczonych ${ }^{16}$, po raz pierwszy w historii skorzystała z mechanizmu (zwanego triggering procedure) przewidzianego w art. 13 Statutu MTK, a umożliwiającego jej zreferowanie sprawy do Trybunału, w sytuacji wskazującej na popełnienie zbrodni ${ }^{17}$. Rezolucja dotyczyła sytuacji w Sudanie stanowiącej zagrożenie dla międzynarodowego pokoju i bezpieczeństwa, w szczególności zaś naruszeń mających miejsce w prowincji Darfur od 2002 r. Rezolucja nakładała na Sudan i pozostałe strony konfliktu w Darfurze obowiązek pełnej współpracy z Trybunałem i jego prokuratorem i zapewnienia im wszelkiej niezbędnej pomocy. W rezolucji odniesiono się także do państw niebędących stronami Statutu, wskazując, że choć nie są związane zobowiązaniami z niego wynikającymi RB zachęca $\left(\right.$ urges $\left.^{18}\right)$ je i organizacje międzynarodowe do pełnej współpracy. W dokumencie Rada zwracała się także do Unii Afrykańskiej (dalej jako UA), stanowiącej obecnie ważny podmiot decyzyjny w regionie, o rozważenie praktycznych ułatwień, które wsparłyby pracę prokuratora, włączając $\mathrm{w}$ to prowadzenie postępowań w regionie, co mogłoby przyczynić się do zwiększenia regionalnych wysiłków na rzecz walki z bezkarnością zbrodniarzy.

${ }^{13} \mathrm{~W}$ szczególności wymienia się dobre usługi, zob. decyzja Zgromadzenia ICC-ASP/10/ Res.5, annex, na stronie: http://www.icc-cpi.int/iccdocs/asp_docs/Non-coop/ICC-ASP-10-Res. 5-extract-annex-ENG.pdf (akces lipiec 2014).

${ }^{14}$ W niektórych przypadkach (zob. art. 87 ust. 5 (a) Statutu) MTK może zwrócić się do Zgromadzenia Ogólnego lub Rady Bezpieczeństwa, ale po pierwsze nie są to działania natury prawnej, ale politycznej, po drugie zaś, jak wskazuje dotychczasowa praktyka MTK, na razie są to działania nieskuteczne, por. szeroko na ten temat w raporcie The Rule of Law: The Security Council and Accountability, 1 Security Council Report 2013, z 28 stycznia 2013 r., na stronie: http://www.securitycouncilreport.org/atf/cf/\%7B65BFCF9B-6D27-4E9C-8CD3-CF6E4FF96FF9\%7D/cross_cut ting_report_1_rule_of_law_2013.pdf.

${ }_{15} \mathrm{SC}$ res $1593(2005)$.

16 Por. Dz. U. z 1947 r., nr 23, poz. 90.

17 Po raz drugi RB wykorzystała ten mechanizm, referując do MTK wydarzenia w Libii od dnia 15 lutego 2011 r., por. SC res 1970 (2011).

${ }^{18}$ Słowo zachęca (urge) ma tu pierwszorzędne znaczenie, gdyż nie stanowi to zobowiązania (oblige), a jedynie nakłanianie do podjęcia współpracy. 
Stosownie do treści art. 25 Karty Narodów Zjednoczonych na każdym państwie, członku ONZ, ciąży obowiązek przyjęcia i wykonywania rezolucji Rady. Sudan jest członkiem ONZ od 1956 r., a więc i na nim ciążą zobowiązania wynikające z Karty. Musi zatem wykonywać rezolucje RB i co za tym idzie w wykonaniu rezolucji 1593 i art. 89 Statutu powinien wykonać zobowiązanie polegające na współpracy z Trybunałem i prokuratorem MTK, pomimo że nie jest stroną Statutu MTK.

Powstaje jednak zasadnicze pytanie o zakres współpracy Sudanu z Trybunałem, rezolucja bowiem tego nie precyzuje. Można brać pod uwagę kilka możliwości. O ile jednak Państwa strony Statutu są zobowiązane do pełnej z nim współpracy stosownie do części IX Statutu, niewątpliwie takiego zakresu współpracy nie można oczekiwać od państw niebędących jego stronami.

Sekretariat MTK, działając w oparciu o rezolucję 1593 i dwa wydane nakazy aresztowania, sformułował szereg wniosków kierowanych zarówno do państw stron Statutu ${ }^{19}$, jak i do państw niebędących stronami Statutu, ale będących członkami $\mathrm{RB}^{20}$, jak i do państw niebędących stronami Statutu ani członkami Rady, ale będących państwami członkowskimi ONZ21 a także do Sudanu ${ }^{22}$. Wnioski dotyczą współpracy wymienionych państw z MTK. Zakres tej współpracy nieznacznie różni się w zależności od tego, do kogo kierowany jest wniosek. Generalnie we wszystkich wnioskach chodzi o pełną współpracę z Trybunałem, a w szczególności aresztowanie i wydanie Al Bashira, a także: zapewnienie bezpieczeństwa świadkom i pokrzywdzonym; dostarczenie dokumentów, informacji, które mogą być pomocne w kontekście wydania Al Bashira; podanie informacji, kiedy możliwe będzie jego dostarczenie; czy w końcu samo jego dostarczenie do MTK. Jedynie we wniosku kierowanym do Sudanu Sekretariat zwraca uwagę na konieczność wykonywania przez Sudan zobowiązań wynikających z rezolucji Rady Bezpieczeństwa, które to zobowiązania przeważają nad jego innymi zobowiązaniami międzynarodowymi. We wniosku pokreślono, że jeżeli Sudan nadal nie będzie się wywiązywał z obowiązku współpracy z Trybunałem, sprawa zostanie zreferowana Radzie, która władna jest podjąć określone środki „przymuszające” państwo do współpracy.

W świetle przedstawionych dokumentów wnioskować można, że współpraca państwa powinna polegać na aresztowaniu lub wydaniu Al Bashira do MTK. Jeśli jednak jest on urzędującą głową państwa, immunitet chroni go zarówno przed aresztowaniem, jak i osądzeniem. Tak więc należałoby zastanowić się, czy współpraca z Trybunałem nie powinna dotyczyć w szczególności zrzeczenia się przez Sudan immunitetu wobec Al Bashira. Rada Bezpieczeństwa może przymuszać do współpracy z Trybunałem, natomiast, czy oznacza to, że może uchylić

\footnotetext{
${ }^{19}$ Por. ICC-02/05-01/09-96.

${ }^{20}$ Por. ICC-02/05-01/09-97.

21 Por. ICC-02/05-01/09-99.

${ }_{22}$ Por. ICC-02/05-01/09-101.
} 
immunitet urzędującej głowy państwa, a co za tym idzie pozbawić państwo przysługujących mu uprawnień? Niewątpliwie nie, jeśli wyraźnie nie wyraziła takiego żądania w rezolucji.

Kwestia współpracy z Trybunałem ma także swój drugi wymiar. UA już w lipcu 2009 r. oficjalnie odmówiła współpracy z Trybunałem w kontekście nakazu aresztowania wydanego przeciwko Al Bashirowi ${ }^{23}$. Ponieważ do UA należy ponad 50 państw, z tego 34, które są jednocześnie stronami Statutu, dla Trybunału powinien być to wyraźny znak niechęci w stosunku do wydanego nakazu. W szczególności zaś UA negatywnie ocenia fakt, że nie odroczono wszczęcia postępowania przygotowawczego stosownie do art. 16 Statutu MTK ${ }^{24}$. Unia powtórzyła te zarzuty w decyzji Zgromadzenia z 27 lipca 2010 r. $^{25}$, nazywając działania prokuratora MTK w odniesieniu do Al Bashira niedopuszczalnymi, niegrzecznymi i protekcjonalnymi. W kolejnych decyzjach Unia Afrykańska konsekwentnie wyraża swoje stanowisko dotyczące odroczenia postępowania wobec Bashira i niechęci wobec toczonych przez MTK postępowań ${ }^{26}$.

Nieco łagodniejsza w wymowie była rezolucja Ligi Arabskiej ${ }^{27}$ wyrażająca jedynie „głębokie zaniepokojenie” wydanym nakazem aresztowania; przywołująca jednocześnie w tym kontekście kwestie suwerenności, jedności i stabilności Sudanu; nazywająca działalność MTK próbą upolitycznienia sprawiedliwości międzynarodowej; wskazująca na kwestię immunitetu Al Bashira; podkreślająca rozgoryczenie $\mathrm{z}$ powodu nieodroczenia postępowania przygotowawczego stosownie do art. 16 Statutu MTK. Liga Arabska zwróciła też uwagę, że decyzja dotycząca nakazu aresztowania utrudni osiągnięcie pokoju w regionie ${ }^{28}$.

${ }^{23}$ Zobacz decyzję Unii na stronie: Decision On The Meeting of African States Parties to The Rome Statute of The International Criminal Court (ICC), http://www.au.int/en/sites/default/files/ASSEMBLY_EN_1_3_JULY_2009_AUC_THIRTEENTH_ORDINARY_SESSION_DECISIONS_DECLA RATIONS_\%20MESSAGE_CONGRATULATIONS_MOTION_0.pdf (akces lipiec 2014).

${ }^{24}$ Warto odnotować fakkt, że Unia Afrykańska stara się o zmianę treści art. 16 Statutu, zobacz obszerne studium na ten temat na stronie: http://www.iss.co.za/uploads/PositionPaper_ICC.pdf.

${ }^{25}$ Decision on the progress report of the commission on the implementation of decision, Assembly/au/dec.270(XIV) on the second ministerial meeting on the Rome statute of the International Criminal Court (ICC), Doc. Assembly/AU/10(XV), http://www.au.int/en/sites/default/files/ASSEMBLY_EN_25_27_July_2010_BCP_ASSEMBLY_OF_THE_AFRICAN_UNION_Fifteenth Ordinary_Session.pdf (akces 27 czerwca 2014).

${ }^{26}$ Decision on the Progress Report of the Commission on the Implementation of the Decisions on the International Criminal Court - Doc. Assembly/AU/13(XXII), Assembly/AU/Dec.493. (XXII), 30-31 stycznia 2014, na stronie: http:/www.au.int/en/sites/default/files/Assembly\%20 AU\%20Dec\%20490-516\%20\%28XXII\%29\%20_E.pdf (akces 27 czerwca 2014).

27 Resolution on the decision of Pre-Trial Chamber 1 to the International Criminal Court against the President of the Republic of Sudan, Hassan Ahmad Al Bashir, http://www.coalitionfortheicc. org/documents/09_03_04_AL_Resolution_on_Omar_Al-Bashir_\%28EN\%29_Unofficial_Translation_\%282\%29.pdf (akces 27 czerwca 2014).

${ }^{28}$ Wskazywano, że ze względu na wydarzenia w Afryce (wtedy powstania w Egipcie, Tunezji i Libii i związane z tym obalenia rządzących głów państwa) można spodziewać się zmiany układu sił, a co za tym idzie nawet zmiany podejścia tych państw co do postępowania MTK w sprawie Al Bashira. 
Powstaje w tym kontekście ważne dla prawa międzynarodowego zagadnienie dotyczące ewentualnej reakcji RB na tak bezpośrednio wyrażoną krytykę dotyczącą współpracy z Trybunałem, zwłaszcza że dotyczy ona znakomitej części społeczności międzynarodowej. $Z$ drugiej zaś strony podobne protesty miały miejsce w przypadku procesu Slobodana Miloševicia przed Trybunałem jugosłowiańskim, większość negatywnych głosów ucichła jednak, kiedy Milošević został w końcu dostarczony do Hagi.

\subsection{Sprawa Kenyatty i Ruto}

Kenyatta to w Afryce wyjątkowe nazwisko. To nazwisko osoby, która doprowadziła swój kraj do niepodległości. Jomo Kenyatta był nie tylko czołowym przywódcą ruchu wyzwoleńczego Kenii, był także jej prezydentem i premierem. Główny port lotniczy koło Nairobi został nazwany właśnie na jego cześć. Jego syn - Uhuru ${ }^{29}$ - kontynuuje urzędnicze tradycje ojca, choć nie w tak, wydaje się, chwalebny sposób, jest bowiem oskarżony przez MTK o popełnienie zbrodni przeciwko ludzkości w trakcie zamieszek po wyborach w 2007 r.

Kenia jest państwem stroną Statutu MTK (Statut wszedł w życie wobec Kenii 1 czerwca 2005 r.), ciąży więc na niej obowiązek pełnej współpracy z Trybunałem, a co za tym idzie wykonywania jego decyzji.

Jak już zaznaczono wyżej, zanim Kenyatta został prezydentem, przed MTK toczyły się już postępowania dotyczące zbrodni popełnianych przez niego i Ruto, jego późniejszego zastępcę. Kenia składała nawet sprzeciwy wobec dopuszczalności sprawy, próbując dowieść, że w Kenii toczy się postępowanie dotyczące powyborczych zamieszek i w myśl zasady komplementarności Trybunał nie powinien zajmować się tymi sprawami. Sprzeciwy te zostały jednak odrzucone przez Trybunał, jako że postępowania prowadzone w Kenii nie spełniały wymogów testu same conduct/same person ${ }^{30}$.

Sam Kenyatta zapewniał, że pojawi się podczas postępowań przed Trybunałem ${ }^{31}$, tym niemniej rząd kenijski od momentu jego wyboru na prezydenta sprzeciwia się jego osądzaniu przed Trybunałem ${ }^{32}$. Tego samego zdania jest Unia

${ }^{29}$ Co notabene oznacza w języku suahili - wolność.

${ }^{30}$ Szeroko na ten temat K. Wierczyńska, Deference in the ICC practice concerning admissibility challenges lodged by States, [w:] L. Gruszczyński, (red.), Deference in International Courts and Tribunals: Standard of Review and Margin of Appreciation, Wouter Werner, Oxford University Press, 2014, s. 355-370.

31 Zobacz np. relację z forum ekonomicznego tu: http://www.nation.co.ke/news/politics/Kenyatta-promises-to-cooperate-with-ICC/-/1064/1851940/-/osb9igz/-/index.html (akces 27 czerwca 2014).

32 Choć już toczyły się postępowania w sprawie wniosku o postępowanie w sprawie Kenyatty i Ruto in absentia, Trybunał postanowił, że warunkowo można dopuścić nieobecność podczas postępowania przed Trybunałem i wymienił te momenty procesu, kiedy podsądni niezawodnie muszą 
Afrykańska, sugerując w wydawanych decyzjach, że postępowania wobec Kenyatty i Ruto powinny być zawieszone dopóki nie zakończą kadencji na stanowiskach państwowych ${ }^{33}$. W decyzjach Unii pojawia się żądanie odroczenia postępowań w myśl art. 16 Statutu i postanowienie, że obaj podsądni nie pojawią się dopóki do kwestii odroczenia/zwieszenia procesu nie odniesie się $\mathrm{RB}^{34}$.

Abstrahując od argumentów prawnych dotyczących immunitetu urzędującej głowy państwa, UA dość często krytykuje Trybunał także jako narzędzie neokolonialnej polityki zachodniego świata. Zaś państwa afrykańskie, z nielicznymi wyjątkami, nie tylko nie współpracują z Trybunałem, choć są stronami Statutu $\mathrm{MTK}^{35}$, ale jednocześnie choć same kierowały sprawy do MTK na podstawie tzw. self-referrals surowo oceniają fakt, że postępowania trybunału toczą się właściwie jedynie przeciwko Afrykańczykom ${ }^{36}$.

Dla ogólnego obrazu współpracy pomiędzy Kenią, UA i Trybunałem należy wspomnieć także o tym, że prokurator Trybunału Fatou Bensouda złożyła wniosek o odroczenie wszczęcia postępowania wobec Kenyatty z tego powodu, że na skutek wycofywania się świadków, ich śmierci i zaginięćc nie jest ona w stanie sprostać wysokim wymogom dotyczącym dostarczenia dowodów procesowych ${ }^{38}$.

W kontekście przedstawionych faktów możliwość osądzenia Kenyatty i Ruto w Hadze wydaje się jedynie hipotetyczna. Pomimo że Kenia jest stroną Statutu, opór państw afrykańskich i UA przed osądzaniem osób objętych immunitetami będzie w tym zakresie kluczowy, choć istnieją powody, dla których immunitet urzędującej głowy państwa może być zniesiony i w tym wypadku jest to popełnienie zbrodni objętych jurysdykcją MTK.

być obecni, zob. Decyzja w sprawie Kenyatty: Decision on the Prosecution's motion for reconsideration of the decision excusing Mr Kenyatta from continuous presence at trial, ICC-01/09-02/11863, 26 listopada 2013; w sprawie Ruto: AC, Judgment on the appeal of the Prosecutor against the decision of Trial Chamber V(a) of 18 June 2013 entitled „Decision on Mr Ruto's Request for Excusal from Continuous Presence at Trial”, ICC-01/09-01/11OA5, 25 października 2013.

${ }_{33}$ Decision on Africa's Relationship with the International Criminal Court (ICC), Ext/Assembly/AU/Dec.1(Oct.2013), 12 października 2013, http://summits.au.int/en/sites/default/files/Ext\%20 Assembly\%20AU\%20Dec\%20\&\%20Decl\%20_E.pdf (akces 27 czerwca 2014).

${ }^{34}$ Rezolucja Rady Bezpieczeństwa, która miała dotyczyć odroczenia postępowania wobec Kenyatty nie została przyjęta, głosowało za nią jedynie 7 członków RB, http://www.un.org/apps/ news/story.asp?NewsID=46499\#.U61dikCFet9 (akces 27 czerwca 2014).

${ }^{35}$ Można powołać się choćby na kazus Czadu, który choć jest stroną Statutu nie wykonuje obowiązku współpracy z Trybunałem i nie wykonuje nakazów aresztowania wydanych przez MTK wobec odwiedzających go osób, na których ciążą zarzuty dotyczące popełniania zbrodni objętych jurysdykcją Trybunału, zob. np. wniosek o współpracę z MTK skierowany do Czadu przed jedną z wizyt: http://www.icc-cpi.int/iccdocs/doc/doc1585403.pdf (akces lipiec 2014).

${ }_{36}$ Zob. argumenty Stephena Lamony w poście Is the International Criminal Court really picking on Africa? dostępny na stronie: http://africanarguments.org/2013/04/16/is-the-internationalcriminal-court-really-picking-on-africa-by-stephen-a-lamony/ (akces lipiec 2014).

37 Zob. np. tu: http://www.bbc.com/news/world-africa-21382339 (akces lipiec 2014).

${ }^{38}$ Zob. stanowisko prokurator tu: http://www.icc-cpi.int/iccdocs/PIDS/wu/ED194_ENG.pdf. 


\section{Immunitet głowy państwa w postępowaniach przed sądami międzynarodowymi. Zagadnienia ogólne}

Międzynarodowy Trybunał Sprawiedliwości w orzeczeniu w sprawie Kongo przeciwko Belgii wskazał w odniesieniu do urzędującego ministra spraw zagranicznych, że ten, będąc za granicą, posiada pełny immunitet w zakresie jurysdykcji karnej i nietykalności. Ten immunitet i nietykalność chronią go przed działaniem jakichkolwiek aktów władczych innego państwa, które mogłyby przeszkodzić mu w wykonywaniu jego obowiązków ${ }^{39}$. Z tego powodu nie można dokonywać rozróżnienia pomiędzy aktami wykonywanymi w ramach obowiązków służbowych a aktami prywatnymi w czasie sprawowania przez niego urzędu ${ }^{40}$. Jednocześnie MTS, choć sama sprawa dotyczyła osoby ministra spraw zagranicznych, zauważył, że zajmuje on w prawie międzynarodowym pozycję jak głowa państwa czy rządu i jest traktowany jako przedstawiciel państwa tylko na podstawie stanowiska, które zajmuje ${ }^{41}$. Trybunał wskazał, że nie da się wywieść żadnego wyjątku od zasady immunitetu od jurysdykcji karnej, nawet jeśli dana osoba - będąca urzędującym ministrem - jest podejrzana o popełnienie zbrodni wojennych czy zbrodni przeciwko ludzkości ${ }^{42}$.

Choć cytowany wyrok MTS nie precyzuje, jakiej ochronie podlega urzędująca głowa państwa, to jednak na jego podstawie i dokonanych przez MTS porównań można wywodzić, że urzędująca głowa państwa podlega nie mniejszej ochronie niż urzędujący minister spraw zagranicznych. A więc w szczególności urzędująca głowa państwa nie podlega jurysdykcji karnej innego państwa, a ochrona dotyczy także zakazu aresztowania. Ochrona przed aresztowaniem i skazaniem ma charakter absolutny i obejmuje nawet oskarżenia o popełnienie międzynarodowych zbrodni.

Co ważne, Trybunał wskazał, że posiadanie immunitetu nie jest równoważne z bezkarnością danej osoby, wymienił także instytucje posiadające kompetencje do osądzenia danej osoby. Na pierwszej pozycji znalazły się sądy krajowe, gdyż urzędujący minister nie jest wyposażony w immunitet od jurysdykcji karnej w swoim własnym państwie. Po drugie, istnieje możliwość zrzeczenia przez państwo immunitetu, w tym wypadku dana osoba mogłaby podlegać sądom zagranicznym. Po trzecie, kiedy dana osoba przestaje sprawować urząd, nie chroni jej już immunitet prawa międzynarodowego i może zostać skazana za czyny popełnione przed lub po sprawowaniu funkcji urzędowej.

${ }^{39}$ Sprawa nakazu aresztowania z 11 kwietnia 2000 (Kongo przeciwko Belgii), Wyrok, 14 luty 2002, pkt 54, I.C.J. Reports 2002, s. 3, http://www.icj-cij.org/docket/files/121/8126.pdf.

40 Ibidem, pkt 55.

41 Ibidem, pkt 53.

42 Ibidem, pkt 58. 
Po czwarte, dana osoba może zostać postawiona przed międzynarodowymi trybunałami karnymi, zarówno stałym, jak i trybunałami ad hoc, które posiadają jurysdykcję w tym zakresie ${ }^{43}$.

Dotychczasowa praktyka dotyczyła głównie ochrony funkcjonariuszy przed jurysdykcją obcego państwa ${ }^{44}$, dlatego wydaje się, że większość możliwości osądzenia funkcjonariuszy, wymienionych w wyroku MTS, powinno się uznać jedynie za teoretyczne. Natomiast nie istnieją wątpliwości w jednym z wymienionych przypadków, a mianowicie w odniesieniu do postawienia funkcjonariusza przed trybunałami międzynarodowymi. Od kilkudziesięciu lat forsują one zasadę odpowiedzialności karnej funkcjonariuszy niezależnie od zajmowanej przez nich pozycji. Statuty trybunałów: tokijskiego, norymberskiego, rwandyjskiego czy jugosłowiańskiego i ich praktyka potwierdzają zasadę, że stanowisko urzędowe nie chroni osoby przed odpowiedzialnością karną.

Dla przykładu warto wskazać, że już Międzynarodowy Trybunał Wojskowy (MTW) w Norymberdze w swoim wyroku z 1 października 1946 r. ${ }^{45}$ wskazywał przede wszystkim, że jednostki mogą być karane za naruszenia prawa międzynarodowego. W wyroku pada powtarzana wielokrotnie w doktrynie prawa międzynarodowego sentencja, że ,zbrodnie przeciwko prawu międzynarodowemu popełniane są przez ludzi, nie abstrakcyjne twory i tylko poprzez karanie jednostek, które te zbrodnie popełniły, postanowienia prawa międzynarodowego będą skuteczne" ${ }^{" 46}$. Interpretując postanowienia Karty MTW w wyroku podkreślono również, że ten, kto narusza prawa wojenne, nie może być chroniony immunitetem, jeśli działa w imieniu państwa, przekraczając jednocześnie kompetencje państwa w prawie międzynarodowym.

Odnosząc się do pozycji jednostki, w powołanym wyroku wskazuje się, że zasada chroniąca reprezentantów państwa nie może się odnosić do aktów, które prawo międzynarodowe uznaje za kryminalne, autorzy tych aktów nie mogą bowiem ukrywać się za swoją oficjalną pozycją, żeby w ten sposób uwolnić się od odpowiedzialności.

Trybunał jugosłowiański potwierdził pozycję tej zasady jako prawa zwyczajowego w swojej decyzji dotyczącej zarzutów procesowych w sprawie Slobodana Milośevicia ${ }^{47}$. Dalej poszedł w swojej decyzji dotyczącej kwestii immunitetu

${ }^{43}$ Ibidem, pkt 60.

${ }^{44}$ Szeroko na ten temat T. Ostropolski, Zasada jurysdykcji uniwersalnej w prawie międzynarodowym, Warszawa 2009.

${ }^{45}$ Wyrok w całości na stronie: http://www.derechos.org/nizkor/nuremberg/judgment/index.html

46 Por. „Crimes against international law are committed by men, not by abstract entities, and only by punishing individuals who commit such crimes can the provisions of international law be enforced", por. Trial of the Major War Criminals before the International Military Tribunal, Nürnberg, 14 November 1945-1 October 1946, Nürnberg, Germany, 1947, s. 223.

47 Por. Prosecutor v. Slobodan Milosevic, Case no. IT-02-54, Decision on Preliminary Motions, 8 listopada 2001, pkt 28 ,There is absolutely no basis for challenging the validity of Article 7, paragraph 2, which at this time reflects a rule of customary international law". 
R. Karadzicia ${ }^{48}$, wskazując, że stosownie do międzynarodowego prawa zwyczajowego istnieją takie czyny, w kontekście których nie można powoływać się na posiadany immunitet ${ }^{49}$. W dalszej części decyzji Trybunał uznał za ugruntowaną praktykę w prawie międzynarodowym, że jakiekolwiek porozumienie dotyczące immunitetu, w sytuacji gdy oskarżony jest posądzany o popełnienie zbrodni ludobójstwa, zbrodni wojennych czy zbrodni przeciwko ludzkości, przed międzynarodowym trybunałem jest nieważne w świetle prawa międzynarodowego ${ }^{50}$.

Potwierdził to Specjalny Trybunał dla Sierra Leone, który w decyzji z 31 maja 2004 r. w sprawie immunitetu od jurysdykcji Charlesa Taylora wskazał, że oficjalne stanowisko skarżącego jako głowy państwa nie stanowi podstawy do zaprzestania osądzania go przed Trybunałem ${ }^{51}$, stwierdzając tym samym, że wysokie stanowisko urzędowe byłego prezydenta nie jest i nie będzie przeszkodą w jego osądzeniu.

Na podstawie przedstawionych przykładów należy uznać osądzanie jednostek bez względu na ich oficjalną pozycję przed trybunałami międzynarodowymi za powszechnie akceptowaną normę zwyczajową. Jak wcześniej wskazano, osądzanie przed trybunałami międzynarodowymi, choć nie można go uznać za najbardziej efektywne w sensie ilości skazanych, jest jednocześnie najbardziej skuteczną formą osądzania wysokich rangą funkcjonariuszy publicznych.

\subsection{Immunitet Bashira w postępowaniu przed MTK}

Centralną pozycję w odniesieniu do immunitetów zajmuje w Statucie rzymskim art. 27 wskazujący na irrelewantność pełnionej funkcji w odniesieniu do odpowiedzialności karnej za zbrodnie wymienione w Statucie. Zgodnie z ustępem 2 art. 27 ,immunitety i inne przywileje związane z pełnioną funkcją nie stanowią przeszkody do wykonywania jurysdykcji Trybunału...". Jest to w pewnym sensie postanowienie unikalne, ,usuwa” bowiem wszelkie immunitety czy przywileje, na jakie mogą powoływać się osoby wypełniające funkcje publiczne. Do tej pory regulacje zawarte w dokumentach międzynarodowych, w szczególności zaś w statutach trybunałów ad hoc, nie wykraczały poza postanowienia zawarte w art. 27 ust. 1 wskazujące, że „Statut ma równe zastosowanie do wszystkich osób (...), w szczególności pełnienie funkcji głowy państwa czy szefa rządu, członka rządu czy parlamentu, wybieralnego przedstawiciela lub funkcjonariusza państwowego

${ }^{48}$ Prosecutor v. R. Karadžić, Case no. 95-5-1/18- PT, Decision on accused's second motion for inspection and disclosure: immunity issue, 17 grudnia 2008.

49 Ibidem, pkt 17.

${ }^{50}$ Ibidem, pkt 25.

${ }^{51}$ Prosecutor v. Charles Ghankay Taylor, Case no. SCSL-2003-01-I, Decision on immunity from jurisdiction, 31 May 2004, pkt 53, http://www.sc-sl.org/LinkClick.aspx?fileticket=7 OeBn $4 \mathrm{RulEg}=\&$ tabid=191. 
w żadnym razie nie może zwolnić sprawcy od odpowiedzialności karnej przewidzianej (...) statutem..." 52 . Wspomniane dokumenty międzynarodowe, m.in. takie jak Karta MTW w art. VII ${ }^{53}$, Karta Trybunału tokijskiego w art. VI ${ }^{54}$ czy statut Trybunału jugosłowiańskiego $\mathrm{w}$ art. 7 i Trybunału rwandyjskiego $\mathrm{w}$ art. 6, a także zasady norymberskie i projekt kodeksu dotyczący przestępstw przeciwko pokojowi i bezpieczeństwu ludzkości ${ }^{55}$ z 1954 r. w art. 3, przewidywały, że stanowisko urzędowe oskarżonych, niezależnie od tego, czy działają jako zwierzchnicy państwa czy jako odpowiedzialni funkcjonariusze rządowi, nie może powodować uwolnienia ich od odpowiedzialności albo złagodzenia kary. Podobne postanowienie znaleźć można w Konwencji dotyczącej zapobiegania i karania zbrodni ludobójstwa ${ }^{56}$, która w odniesieniu do zbrodni ludobójstwa stanowi, że winni jego popełnienia będą karani bez względu na to, czy są konstytucyjnie odpowiedzialnymi członkami rządu, funkcjonariuszami publicznymi czy też osobami prywatnymi. Cytowane dokumenty nie podejmowały kwestii immunitetu, a jedynie tego, że oficjalna pozycja oskarżonego w procesie przed trybunałami jest bez znaczenia. Stąd właśnie unikalność rozwiązania wprowadzonego art. 27 ust. 2 Statutu MTK.

$\mathrm{Z}$ zastosowaniem art. 27 do sytuacji Kenyatty, wbrew sprzeciwowi Kenii i UA, nie powinno być problemów - Kenia jest wszakże stroną Statutu MTK, natomiast ze sprawą Bashira wiążą się pewne problemy. Ponieważ MTK powstał na podstawie umowy państw i wiąże jedynie państwa strony, a nie było i nie ma wśród nich Sudanu, artykuł ten nie może być podstawą do uznania, że Bashir nie jest chroniony immunitetem. Te postanowienia dotyczą jedynie państw, które wyraziły na to zgodę. Sudan nie zrobił tego ani przystępując do Statutu jako strona, ani w deklaracji uznającej jurysdykcję $\mathrm{MTK}^{57}$ czy umowie, którą mógłby ewentualnie z Trybunałem zawrzeć odnośnie do współpracy ${ }^{58}$. Dodatkowo sam Statut stoi na stanowisku ochrony państw niebędących jego stronami odnośnie do aresztowania i dostarczenia osoby do MTK. Artykuł 98 ust. 1 Statutu przewiduje, że Trybunał nie może wystąpić z wnioskiem o dostarczenie lub pomoc, który wymagałby od państwa wezwanego działania niezgodnego z jego zobowiązaniami wynikającymi z prawa międzynarodowego w odniesieniu do immunitetu państwa, immunitetu dyplomatycznego osoby lub majątku państwa trzeciego, chyba

52 Dz. U. z 2003 r., nr 78, poz. 708.

${ }^{53}$ Dz. U. z 1947 r., nr 63, poz. 367.

${ }^{54}$ Art. VI Karty stanowi: Responsibility of Accused. Neither the official position, at any time, of an accused, nor the fact that an accused acted pursuant to order of his government or of a superior shall, of itself, be sufficient to free such accused from responsibility for any crime with which he is charged, but such circumstances may be considered in mitigation of punishment if the Tribunal determines that justice so requires, http://www.stephen-stratford.co.uk/imtfe_charter.htm (akces lipiec 2014).

${ }^{55}$ Na stronie: http://untreaty.un.org/ilc/texts/instruments/english/draft\%20articles/7_3_1954.pdf.

56 Dz. U. z 1952, nr 2, poz. 9.

57 Przewiduje to art. 12 ust. 3 Statutu.

58 Taką możliwość przewiduje art. 87 ust. 5 Statutu MTK. 
że Trybunał wcześniej uzyska zgodę państwa trzeciego na uchylenie immunitetu. Artykuł ten odnosić należy jedynie do państw niebędących stronami Statutu, do stron stosuje się cytowany wyżej art. 27 Statutu dotyczący irrelewantności pełnionej funkcji w odniesieniu do urzędników państwowych ${ }^{59}$. A zatem podsumowując - art. 27 ,usuwa" immunitety w odniesieniu do postępowania przed Trybunałem, ale dotyczy jedynie państw stron Statutu MTK, natomiast w przypadku państw niebędących stronami Statutu stosuje się klasyczne zasady prawa międzynarodowego, stojące na stanowisku ochrony zarówno immunitetu państwa, jak i jego funkcjonariuszy (z brzmienia art. 98 jednoznacznie wynika, że państwo niebędące stroną Statutu musi się uprzednio zgodzić na uchylenie immunitetu).

Dwa nakazy aresztowania z 4 marca 2009 i 12 lipca 2010 wydane przez Trybunał przeciwko Al Bashirowi nie wydają się pomocne w rozwiązaniu tego problemu. Konsekwentnie unikały bowiem podjęcia kwestii immunitetu czy jego zrzeczenia. Nie ma w nich mowy także o zakresie ochrony wynikającej z art. 98 Statutu. Nie można więc z działania Trybunału wywodzić, jak wyobraża on sobie praktyczne ,pociągnięcie” Al Bashira do odpowiedzialności karnej. Również z postanowień Statutu MTK nie da się wywieść żadnych uprawnień dla Trybunału pozwalających mu na decydowanie o obowiązkach państw niebędących stronami Statutu w zakresie odpowiedzialności karnej ich funkcjonariuszy.

\subsection{Wpływ rezolucji Rady Bezpieczeństwa na sytuację Bashira}

W doktrynie sugeruje się jednak, że z faktu, iż to Rada Bezpieczeństwa przekazała sprawę do MTK może wynikać, że państwo, którego dotyczy działanie RB, jest związane zobowiązaniami tak jak państwo strona Statutu MTK, tyle że swoje obowiązki wywodzi ono nie z postanowień Statutu, ale z rezolucji Rady Bezpieczeństwa $1593^{60}$. Dodatkowo wskazuje się, że z obowiązku pełnej współpracy sformułowanego w rezolucji RB wynika również obowiązek uchylenia przez państwo immunitetu ${ }^{61}$.

$\mathrm{Z}$ drugiej strony pojawiają się argumenty przeciwne, wskazujące na to, że Rada nie może ingerować w zakres działania niezależnej międzynarodowej

${ }^{59}$ Choć zdarzają się też opinie odrębne zob. G. P. Barnes, The International Criminal Court's Ineffective Enforcement Mechanisms: The Indictment of President Omar al Bashir, „Fordham International Law Journal" 2011, vol. 34, issue 6, s. 1615.

${ }^{60}$ D. Akande, The legal nature of Security Council Referrals to the ICC and its impact on Al Bashir's immunities, ,Journal of International Criminal Justice” 7 (2009), s. 343-344.

${ }^{61}$ Zobacz dyskusję pomiędzy Marko Milanoviciem, Dapo Akande i Kevinem Hellerem na międzynarodowym blogu prawniczym, http://opiniojuris.org/2008/07/11/icc-prosecutor-to-charge-sudans-president-with-genocide/; także D. Akande, The Bashir Indictment: Are Serving Heads of State Immune from ICC Prosecution?, 20 lipiec 2008, http://www.csls.ox.ac.uk/documents/Akande.pdf. 
instytucji, wyposażonej w osobowość prawną, która nie jest członkiem ONZ ani stroną Karty Narodów Zjednoczonych, a zatem nie jest związana jej postanowieniami, a w szczególności postanowieniami art. $103 \mathrm{Karty}^{62}$.

Należy w pełni uznać to stanowisko za słuszne, wzmacniając je dodatkowymi argumentami.

Po pierwsze, Rada Bezpieczeństwa nie może zmieniać reżimu prawnego niezależnych instytucji międzynarodowych. Choć jej kompetencje wynikające z Karty były do tej pory interpretowane bardzo szeroko (szczególnie w odniesieniu do działań podejmowanych na podstawie rozdziału VII Karty NZ), nie można zgodzić się z argumentem jakoby Rada mogła ingerować w treść aktów, w tym wypadku Statutu MTK, ustanowionych na podstawie zgodnego działania państw. Byłoby to działanie niezgodne z zasadą dobrej wiary, na podstawie której państwa przystępujące do Statutu rzymskiego zgadzały się na objęcie ich konkretnymi postanowieniami Statutu. Nie dopuszczano myśli, że Rada Bezpieczeństwa mogłaby swobodnie interpretować postanowienia Statutu i decydować o jego treści. Uprawnienie Rady do przedstawienia sprawy Trybunałowi (art. 13 punkt b Statutu) nie powinno być interpretowane szerzej niż stanowią to postanowienia Statutu, zwłaszcza że prokurator Trybunału nie jest nawet zobowiązany podjąć czynności w sprawie objętej zawiadomieniem. Wszczyna on/ona postępowanie przygotowawcze jedynie w przypadku, gdy uzna, że istnieje ku temu wystarczająca podstawa (art. 15 Statutu) ${ }^{63}$. Rada nie może zatem decydować w trybie rozdziału VII Karty o tym, które państwo podlega jurysdykcji Trybunału. Rezolucja, w której Rada Bezpieczeństwa przedstawia sprawę Trybunałowi, powinna być traktowana jak dokument dotyczący tylko tej kwestii, a nieodnoszący się jeszcze do szeregu spraw, m.in. zniesienia immunitetu.

Po drugie, z art. 24 ust. 2 Karty wynika, że wypełniając swoje obowiązki (dotyczące utrzymania międzynarodowego pokoju i bezpieczeństwa), Rada Bezpieczeństwa będzie się kierowała celami i zasadami Narodów Zjednoczonych ${ }^{64}$.

${ }^{62}$ Zob. M. Blommestijn, C. Ryngaert, Exploring the Obligations for States to Act upon the ICC's Arrest Warrant for Omar Al-Bashir. A Legal Conflict between the Duty to Arrest and the Customary Status of Head of State Immunity, Zeitschrift für Internationale Strafrechtsdogmatik 6/2010, www.zis-online.com; także R. Cryer, Sudan, Resolution 1593 and International Criminal Justice, „Leiden Journal of International Law”, 19 (2006), s. 213, http://eprints.bham. ac.uk/167/1/Leiden_06_R_Cryer.pdf.

${ }^{63}$ Szeroko na ten temat K. Wierczyńska, Wptyw Rady Bezpieczeństwa i Stanów Zjednoczonych na działalność Międzynarodowego Trybunatu Karnego, Przegląd Zachodni, 3 (308) 2003, s. 184 i nast.

${ }^{64}$ Zasadniczo w doktrynie wskazuje się, że Rada Bezpieczeństwa, działając na podstawie rozdziału VII Karty, jest ograniczona celami i zasadami sformułowanymi w Karcie oraz normami ius cogens, por. E. De Wet, The chapter VII Powers of the United Nations Security Council, Oxford 2004, s. 187 i nast.; B. Martenczuk, The Security Council, The International Court and Judicial Review: What lessons from Lockerbie?, EJIL 1999, Vol. 10, No. 3, s. 636 i nast., http://www.ejil.org/ pdfs/10/3/598.pdf. 
Stosownie do art. 2 ust. 1 Karty Organizacja opiera się na zasadzie suwerennej równości wszystkich swych członków. Rada musi zatem szanować równość i suwerenność państw. Jeśli by jednak za niektórymi przedstawicielami doktryny przyjąć, że rezolucja 1593, nakazując Sudanowi współpracę z Międzynarodowym Trybunałem Karnym, czyni z niego państwo stronę Statutu rzymskiego, oznaczałoby to pogwałcenie tej zasady. Wśród stałych członków Rady Bezpieczeństwa znajdują się państwa, które nie są stronami Statutu (Chiny, USA, Rosja). Naruszeniem zasady suwerennej równości państw byłoby przyjęcie, że decyzja Rady, a więc w gruncie rzeczy decyzja tych państw, może objąć jakieś państwa jurysdykcją MTK wbrew ich woli, zwłaszcza że państwa będące stałymi członkami RB nie postawią siebie nigdy w analogicznej sytuacji.

Po trzecie, wydaje się, że postawienie Sudanu w sytuacji państwa strony Statutu na podstawie rezolucji powinno być dokonane bezpośrednio i wyraźnie. Nie powinno tak być, że to z lakonicznego postanowienia o „pełnej współpracy" wywodzi się koncepcje zmieniające prawną sytuację państwa na arenie międzynarodowej.

Po czwarte - immunitety głów państw wywodzą się z prawa zwyczajowego i choć art. 103 Karty mówi o przeważającej mocy postanowień Karty nad innymi międzynarodowymi porozumieniami, to jeśli brać pod uwagę literę tych postanowień, chodzi jedynie o porozumienia (international agreements), a nie całe prawo międzynarodowe ${ }^{65}$. Należałoby to interpretować w ten sposób, że postanowienia art. 103 nie przeważają nad normami prawa zwyczajowego. Jeśli jednak za częścią doktryny uznać, że postanowienia te odnoszą się także do prawa zwyczajowego $^{66}$, Rada Bezpieczeństwa, żeby je uchylić, musi to konkretnie wyrazić, w szczególności dotyczy to jej działań podejmowanych na podstawie Rozdziału VII Karty ${ }^{67}$, czego RB w odniesieniu do omawianej rezolucji 1593 nie uczyniła.

Reasumując tę część wywodu, wątpliwe jest, czy Rada Bezpieczeństwa mogła uczynić Sudan stroną Statutu i uchylić w drodze rezolucji immunitet jego urzędującego prezydenta. Można natomiast zastanowić się, co wynika z tej rezolucji dla sytuacji Al Bashira. Rezolucja nakłada obowiązek pełnej współpracy jedynie na Sudan, pozostałe państwa i organizacje, do których jest kierowana, są jedynie zachęcane (urges) do współpracy. RB słusznie odnotowuje w omawianej rezolucji, że państwa niebędące stronami Statutu nie mają w odniesieniu do Trybunału

${ }^{65}$ Por. A. Orakhelashvili, Security Council Acts: Meaning and Standards of Review, Max Planck UNYB 11(2007), s. 150.

${ }^{66}$ Zobacz raport grupy roboczej ustanowionej pod kierownictwem M. Koskenniemi, Fragmentation of international law: difficulties arising from the diversification and expansion of international law, International Law Commission, A/CN.4/L.682/Add., 12 maj 2006, http://untreaty.un.org/ ilc/documentation/english /a_cn4_1682_add1.pdf.

${ }^{67}$ A. Aust, The role of human rights in limiting the enforcement powers of the Security Council: a practicioner's view, [w:] Review of the Security Council by member states, red. E. De Wet, A. Nollkaemper, P. Dijkstra, Antwerp-Oxford-New York 2003, s. 34. 
żadnych zobowiązań. W myśl bowiem postanowień art. 35 Konwencji Wiedeńskiej o prawie traktatów ${ }^{68}$, jeśli traktat przewiduje obowiązki dla państwa trzeciego, to państwo musi się wyraźnie na to zgodzić. Oznacza to, że nie domniemywa się zakresu obowiązków wobec państw trzecich. Można więc przyjąć, że ze strony państw niebędących stronami Statutu nie grozi Al Bashirowi niebezpieczeństwo w postaci aresztowania. Żadne nie zgodziło się na przyjęcie takiego obowiązku. Gdyby jednak któreś z nich poczuło się związane rezolucją na tyle, że schwytałoby Al Bashira w momencie, gdyby ten znalazł się na jego terytorium, to państwo ma dwie alternatywy. Mogłoby, działając na podstawie rezolucji, wydać go do Trybunału lub zdecydować, że w tej sytuacji przeważają normy prawa zwyczajowego i uznać się za związane zasadą przyznającą urzędującym głowom państw immunitet absolutny. W gruncie rzeczy immunitet głowy państwa może być przez nią samą powołany nawet na terytorium państwa strony Statutu. Wydaje się, że tak długo, jak Al Bashir cieszy się immunitetem personalnym, państwa niebędące stronami Statutu nie muszą wykonać nakazu aresztowania i nie będzie to oznaczało, że działają niezgodnie z postanowieniami prawa międzynarodowego.

Nie ulega wątpliwości, że sprawcy zbrodni międzynarodowych powinni podlegać odpowiedzialności karnej i najlepszym, jak się wydaje, forum do tego ustanowionym są międzynarodowe trybunały. Jednak kompetencji do osądzania sprawców zbrodni z państw niebędących stronami Statutu nie powinno się wywodzić z politycznych decyzji Rady Bezpieczeństwa, dotyczących ,pełnej współpracy", w których nie sprecyzowano zakresu owej współpracy.

\section{Zakończenie}

Międzynarodowe trybunały karne, zarówno stały, jak te ad hoc czy tzw. hybrydowe, osądzają popełnienie najcięższych międzynarodowych zbrodni, takich jak zbrodnie przeciwko ludzkości czy ludobójstwo. Panuje zgoda w doktrynie, że byłoby paradoksem pozwolić jednostkom odpowiedzialnym za te zbrodnie powoływanie się na immunitet państwa czy jego suwerennośćc ${ }^{9}$. Jednocześnie MTS potwierdził, że trybunały karne są właściwym forum do osądzania urzędujących głów państw. Artykuł 27 Statutu MTK, który wprowadza irrelewantność pełnionych funkcji publicznych i określa immunitety i inne przywileje jako niestanowiące przeszkody w wykonywaniu przez Trybunał jego jurysdykcji, pozwala na osądzenie urzędującej głowy państwa bez względu na przysługujący jej immunitet. Teoretycznie więc MTK mógłby osądzić urzędującego prezydenta Sudanu.

${ }_{69}$ Dz. U. z 1990 r., nr 74, poz. 439, zał.

69 Zob. choćby A. Watts, op. cit., s. 1705. 
Kłopot polega na jego dostarczeniu do Trybunału, a stoją temu na przeszkodzie postanowienia art. 98 nakładające ograniczenia na Trybunał w wydaniu wniosku o dostarczenie i wydanie osoby chronionej immunitetem, chyba że państwo trzecie wyrazi zgodę na uchylenie immunitetu.

Ponieważ, jak wskazywano w opracowaniu, rezolucja 1593 nie ma mocy uczynienia z Sudanu państwa strony Statutu, wobec tego jak najbardziej odnoszą się do niego uregulowania art. 98 Statutu. Najwłaściwszym byłoby więc stwierdzenie, że z rezolucji Rady nie wynika obowiązek uchylenia immunitetu, sama rezolucja nie uchyla go wyraźnie, a więc może się okazać, że alternatywą będzie przeczekanie, aż Al-Bashir złoży swój urząd.

Sprawa Bashira niewątpliwie nie będzie sztandarową sprawą MTK, raczej Trybunał, wydając prośby o współpracę, przekroczył swoje kompetencje, działając poza uregulowaniami art. 98. Jeżeli sędziowie kierują się politycznymi rezolucjami, a nie postanowieniami Statutu, to źle wróży instytucji, która jest dopiero na początku swej drogi i ma przekonać oponentów do swojej działalności. Sama sprawa jest ciekawa o tyle, że niewątpliwie mamy tu do czynienia ze zderzeniem trzech reżimów prawnych. Tego odnoszącego się do Statutu MTK, reżimu związanego z Rozdziałem VII Karty i rezolucją RB, i w końcu z reżimem zwyczajowego prawa międzynarodowego. W tym momencie jednak nie sposób wskazać, które z nich mają moc przeważającą i powinny być stosowane w pierwszej kolejności.

Osądzenie osoby chronionej immunitetem nastręcza trudności, także w przypadku państwa będącego stroną Statutu, czego dowodzą sprawy Kenyatty i Ruto przed Trybunałem. Problemu zatem należy doszukiwać się nie w tym czy państwo jest stroną Statutu czy nie, ale czy osoba oskarżana jest urzędującą głową państwa czy nie. Dowodzi tego podjęta właśnie decyzja UA, aby chronić urzędujące głowy państw oraz wyższych urzędników przed zarzutami przeciwko nim w Afrykańskim Sądzie Sprawiedliwości oraz Praw Człowieka dopóki sprawują oni swoje funkcje ${ }^{70}$. UA od dawna podkreśla, że osądzanie urzędujących głów państw stanowi zagrożenie dla procesu pokojowego i pojednania w regionie.

$\mathrm{Z}$ drugiej strony należy pamiętać o tym, że państwa afrykańskie przystosowały swoje ustawy zasadnicze do wymogów statutu MTK - abstrahując od oporu odnoszącego się do osądzania urzędujących głów państw - ustawodawstwo państw stron Statutu MTK przewiduje karanie niezależnie od ochrony przysługującej głowom państw.

Wnioski, które nasuwają się odnośnie do omawianych zagadnień, mieszczą się w głównej mierze w polu politologicznych rozważań. Dotyczą bowiem rekomendacji dla Trybunału, Zgromadzenia Państw Stron i RB, aby zrewidowały politykę wobec państw afrykańskich. Bez wsparcia UA nie będzie można liczyć

${ }^{70} \mathrm{O}$ zmianach w protokole Sądu donosi Amnesty International, wskazując, że sama UA nie podała tego jeszcze do oficjalnej wiadomości na swojej stronie, zob. http://www.amnesty.org/en/ for-media/press-releases/au-summit-decision-backward-step-international-justice-2014-07-01 (akces 8 lipca 2014). 
na efektywną współpracę w tym rejonie. Można też zastanowić się nad zmianami Statutu (choćby poprawkami dotyczącymi art. 98 Statutu $^{71}$ czy zwiększeniem uprawnień Zgromadzenia Państw Stron np. w kontekście zawieszenia w prawach państwa strony naruszającej zobowiązania wynikające ze Statutu), choć jak się wydaje problem leży gdzie indziej. Tak jak każda osoba fizyczna wykorzysta wszelkie możliwe środki, aby ochronić się przed odpowiedzialnością, tak samo zachowa się też urzędująca głowa państwa. Wykorzysta wszelkie możliwe środki (ucieknie się do manipulacji, zastraszania świadków i innych przestępstw), aby się bronić i ochronić przed odpowiedzialnością karną. I to jest kazus Al Bashira, Kenyatty i Ruto. Takie zachowanie z jednej strony uzasadnia istnienie MTK (jako sądu last resort), a z drugiej, wobec niemożliwości osądzenia tych osób, stanowi o wielkiej słabości tej instytucji.

\footnotetext{
${ }^{71}$ Zob. Krzan, op. cit., s. 80 i nast.
} 